\title{
Effect of Seeding Rates and Weed Control Treatments on Productivity and Weed Suppression in Flax Cultivar Sakha 4
}

\author{
Abou-Zied ${ }^{1}$, K. A., Sanaa ${ }^{2}$, S. Hassan, Khalil ${ }^{3}$, H. E. and Nawar ${ }^{4}$, A. I. \\ ${ }^{1}$ Weed Research Central Laboratory, Agricultural Research Center, Giza, Egypt \\ ${ }^{2}$ Fiber Crop Research Department, Field Crop Research Institute, Agricultural Research Center, \\ Giza, Egypt. \\ ${ }^{3}$ Intercropping Research Department, Field Crop Research Institute, Agricultural Research Center, \\ Giza, Egypt. \\ ${ }^{4}$ Crop Science Department, Faculty of Agricultural, Alexandria University, Egypt.
}

\section{ABSTRACT}

A two years field experiment was conducted during 2012/2013 and 2013/2014 winter seasons at Agricultural Research Station, Alexandria University, to study the effect of three seeding rates $(30,45$ and $60 \mathrm{~kg} / \mathrm{fed}$.) and eight weed control treatments on agronomic characters of flax cultivar Sakha 4 and its companion annual weeds.

Increasing seeding rates had insignificant effect on broad, narrow and total weeds dry weight in the two seasons. Application of a combination of Brominal and Select Super was superior to hand weeding twice and individual application of pre-emergence or post-emergence herbicides in reducing both categories and total weed dry weights.

As seeding rate increased plant height, technical length, seed and biological yields increased significantly from the lowest to the highest seeding rate, whereas number of capsules per plant, 1000 seed weight, fruiting zone length, number of basal and apical branches and seed yield per plant were significantly decreased. Application of post-emergence herbicide combination of Brominal + Select Super gave significantly improved values for seed yield and yield components compared to individual herbicide application, pre or post-emergence, and was comparable or superior to hand weeding twice in both seasons.

\section{Key words: Flax, seeding rate, weed control, seed yield.}

\section{INTRODUCTION}

Flax (Linum usitatissmum, L.), an important oil and fiber crop in Egypt, occupies a limited cultivated area in Egyptian corporation due to constraints in marketing, weed problems and the competition of flax with other winter crops for cultivated area.

Plants with large leaf area index have higher competition ability with weeds than those lower in such trait. Both light quality and quantity are important aspects regarding competition. Since the presence of dense leaf canopy reduces light availability to weeds, competition for light is greatest (Swanton and Wiese, 1991). Increase in weed density, as crop density decreases, lead to a reduction in soil resources availability to the companion crop and in turn lead to crop productivity decline.

Weeds have many attributes, undesirable to crop production, not the least being their ability to reduce crop productivity, but they also may be hosts for certain pathogens. Plant type and population density, in addition to weed control, can greatly decrease weed competition with crop plants for growth resources.

Flax is a very poor competitor with weeds in early stages of growth and to achieve its higher seed and fiber yields, optimum seeding rate and appropriate methods of weed control should be applied. Increase in seeding rates modifies canopy distribution to enhance the crop ability to compete with weeds. Herbicides, as a chemical weed management practice, are considered the most common method for controlling weeds and important in contributing, with crop higher density, to weeds suppression and yield increases. Although higher seeding rates provide enough plants to compete with weeds, the use of herbicides is indispensable and may reduce the need for these higher populations for weeds suppression (Lafond, 1993). Stevenson and Wright (1996) demonstrated that reduction in flax seed yield, due to weeds, decreased in response to greater seeding rates than those commonly used.

Use of herbicides for weed control in flax is essential for several reasons including: 1) the slow growth in early stages that allows weeds, of faster growth and higher adaptability, to compete with crop plants, 2) the presence of weeds adapted to growth at higher crop plant densities such as field bind weed (Cunvolvulus arvensis, L.) and 3) the crop dense stands limits the use of other methods of weed control such as mechanical or manual hoeing.

Hand weeding is not only a traditional method for weed control, but it is also expensive and causes 
damage for plants. Therefore, using herbicides as alternative technology for weed control eliminates crop plants injury and, in turn, improve crop productivity. Many investigators recommended several herbicides as effective control methods against broad-leaved weeds, such as Granstar (Mousa, 2002 and Osman et al., 2010). However Abd-El-Samie and Abd-El-Dayem (2000) and Osman et al. (2010) found, in divergent studies, that Fusilade showed effective weed control against grass weeds, compared to unweeded check treatment.

Different studies were conducted to investigate the response of plant height, stem diameter, 1000 seed weight and seed yield/fed to herbicide treatments (Kassem, 1992; Ghalwash and Soliman, 2007 and Osman et al., 2010).

This investigation was conducted to study the effect of seeding rates and different weed contro treatments on agronomic characters and productivity of flax and its companion annual weeds.

\section{MATERIALS AND METHODS}

A two years field study was conducted during $2012 / 2013$ and 2013/2014 winter seasons at the Agriculture Research Station, Alexandria University, to study the effect of three seeding rates and eight weed control treatments on flax plant (Sakha 4 cultivar) and its companion annual weeds. Flax seeding rates were 30,45 and $60 \mathrm{~kg} / \mathrm{fed}$ however, the weed control treatments were Stomp (1.25 L/fed), Select Super $(0.25 \mathrm{~L} / \mathrm{fed})$, Brominal ( $0.5 \mathrm{~L} / \mathrm{fed})$, Granstar (6 $\mathrm{g} / \mathrm{fed})$, the combinations of Select Super and Brominal, Select Super and Granstar, hand weeding twice (after three and six weeks from sowing) and unweeded contro treatment (check). The trade and common names, as well as the chemical structures, use and time and rate of application of studied herbicides, are presented in Table (1).

Soil at the experimental site was clay-shell with the following chemical characteristics: $\mathrm{pH}=8.2$ total organic matter $=1.1 \%$, available $\mathrm{N}=35.6$ ppm, available $\mathrm{P}=10.5 \mathrm{ppm}$ and available $\mathrm{K}=$ $610.0 \mathrm{ppm}$. The design used was the split-plot with three replicates, in which the flax seeding rates and weed control treatments occupied, respectively, the main and sub plots. Each sub plot comprised 10 rows, $20 \mathrm{~cm}$ apart and $3 \mathrm{~m}$ in length (Subplot area = $6 \mathrm{~m}^{2}$.

Flax seeds were hand drilled, in the sub plots rows, on November 10 and 12 for the first and second season, respectively.

After 60 days from sowing, weeds were hand pulled at random from one square meter for each sub plot, weeds were classified into broad-leaved and grassy weeds and dry weight of each category and total weeds were recorded after oven drying at $70 \mathrm{c}^{\circ}$ for $24 \mathrm{hrs}$ until constant weight.

Annual weed species prevalent at the experimental site included broad-leaved weeds (Malva parviflora, Chenopodium murale, Brassica nigra and Vivia sativa) and narrow-leaved (grassy) weeds (Avena fatua, Lolium temulentum and Phalaris paradoxa). Population of grassy weeds comprised 62 to $64 \%$ of the total weed population in the two seasons.

At full maturity stage, representative samples of 20 plants were randomly selected from each experimental unit to determine flax growth aspects of plant height $(\mathrm{cm})$, technical length $(\mathrm{cm})$, fruiting zone length $(\mathrm{cm})$ and number of basal and apical branches/plant in addition to number of capsules/plant, 1000 seed weight and seed yield/plant. The inner eight rows were harvested to calculate the seed and straw yields for each sub plot, then converted to yields/fed $(\mathrm{kg})$.

Statistical analysis of data was conducted according to Gomez and Gomez (1984) using SAS (Statistical Analysis System) ver. 9.01.

\section{RESULTS AND DISCUSSION}

The present investigation was conducted to determine the effect of seeding rate and weed control treatments on weed population, seed yield and yield components and agronomic characters of flax variety Sakha 4 . The results obtained from the present study will be presented as follows:

I. Effect of seeding rate and weed control treatments on weeds population:

Statistical analysis revealed that seeding rate had insignificant effect on weed population in both seasons whereas applied weed control treatments significantly affected broad, narrow and total weeds dry weight in both seasons. The interaction between seeding rate and weed control treatments significantly affected broad-leaved weeds dry weight in the two seasons.

With regard to seeding rate, means presented in table (2) indicated that there was a trend for decrease in both weed categories and total weeds dry weight with increasing seeding rate up 60 $\mathrm{kg} / \mathrm{fed}$. That may be attributed to the ability of flax plants to compete with weeds, especially broadleaved species with similar growth habit, thus suppressing their growth.

Siddique et al. (2003) concluded that changing the seeding rate alters competition above and below ground between flax and associated weeds. However, that effect was insignificant in both seasons and that may be due to the application of herbicides to control weeds. Stevenson and Wright (1996) concluded that when herbicides were used to control weeds in flax, no advantage was observed with changes in seeding rates. 
With respect to weed control treatments, data presented in table (2) indicated that all weed control treatments exerted significant reduction in the dry weight of broad-leaved, narrow-leaved and tota weeds compared to the unweeded control, in both seasons, depending on the selectivity of the applied herbicide. The pre-emergence herbicide Stomp gave moderate control for both categories of weeds Brominal and Granstar gave significant reduction in dry weight of broad-leaved weeds, but had no effect on narrow-leaved weeds hence the total weeds dry weight was relatively high. Similarly, application of Select Super resulted in a significant reduction in dry weight of narrow-leaved weeds, but had no effect on broad-leaved weeds, thus total weeds dry weight was relatively high. The most pronounced effect was observed for herbicides combinations, Brominal + Select Super and Granstar + Select Super, where they significantly reduced the dry weight of both categories of weeds and total dry weight of weeds in both seasons.

Herbicide combinations gave similar weed control values to the traditional method of hand hoeing twice. Similar finding were reported by Kassem (1992), Abd-El-Samie and Abd-El-Dayem (2000), Mousa (2002) and Osman et al. (2010) using different herbicides and herbicide combinations.

The interaction between seeding rate and weed control treatments had significant effect on dry weight of broad-leaved weeds only in the two seasons. Obtained data for that interaction (tables 5 and 6) showed a significant superiority of Bromina and Granstar, which are specific post-emergence herbicides for broad-leaved weeds over the pre emergence herbicide Stomp, the combinations of those two herbicides with Select Super and hand weeding twice in both seasons. The differences were more pronounced at lowest and highest seeding rates compared to the intermediate rate. Also, herbicides combinations were superior to hand weeding twice in reducing dry weight of broadleaved weeds, in the second season, at lowest and highest seeding rates compared to the intermediate rate. The data, also, cleared the effect of seeding rate on dry weight of broad-leaved weeds where it could be observed, in the check, that increasing seeding rate resulted in a significant reduction in dry weigh of broad-leaved weeds in both seasons. These findings are in agreement with those reported by Abd El-Samie and Abd El-Dayem (2000), Mousa (2002) and Osman et al. (2010) who reported that all weed control treatments exerted significan reduction in the dry weight of broad-leaved weeds, and the magnitude of reduction was closely related to the applied seeding rate of flax.

\section{Effect of seeding rate and weed control} treatments on agronomic characters of flax:

Statistical analysis showed that both seeding rate and weed control treatments had significant effects on all studied agronomic characters of flax in the two seasons. Moreover, the interaction between the two studied factors was significant for technical length, 1000 seed weight, number of basal branches and seed yield/plant in the two seasons, whereas it was significant for fruiting zone length in the second season only.

As seeding rate increased (tables 3 and 4) plant height, technical length, seed and biological yield per feddan increased significantly from the lowest to the highest seeding rate, in both seasons. On the contrary, number of capsules per plant, 1000 seed weight, fruiting zone length, number of basal and apical branches per plant and seed yield per plant decreased significantly from the lowest to the highest seeding rate in both seasons. The data indicated that the flax plant tended to perform as a fiber producing plant with taller plant height and technical length, in addition to fewer basal and apical branches, at higher seeding rates, whereas it tended to perform as an oil producing crop with higher 1000-seed weight and number of capsules per plant leading to higher seed yield per plant at lower seeding rates. These results were similar to those reported by other researchers for plant height (Mostafa, 2003 and El-Deeb et al., 2006), technical length (Abd El-Daiem, 2004), 1000 seed weight (Abou-Zaid and Al-Azony, 2003), number of capsules per plant (Kineber, 2003 and Siddique et al., 2003), seed and biological yields (Stevenson and Wright, 1996 and Kineber et al., 1997), number of basal and apical branches per plant (Stevenson and Wright, 1996) and seed yield per plant (Siddique et al., 2003 and Zedan, 2004).

Concerning the effect of weed control treatments, means presented in table (3 and 4) indicated a significant effect for applied weed control treatment on all studied agronomic characters of flax in the two seasons.

Application of post-emergence herbicides combination, especially Brominal and Select Super, was superior to application of individual pre or postemergence herbicides in all seed yield and yield components, and was either comparable or superior to hand weeding twice. However, the weedy check recorded higher values for plant height and technical length, with lowest values for number of basal and apical branches per plant. That might be explained by the higher competition exerted on the flax plant by weeds population in the unweeded check. Otherwise, the weedy check was significantly inferior to weed control treatments. 
These findings were in harmony with those reported by Kassem (1992), Abd El-Samie and Abc El-Dayem (2000) and Mousa (2002). However, Ghalwash and Soliman (2007) and Osman et al (2010) reported that weed control treatments had significant effect on 1000 seed weight and seed yield.

Means for the interaction between the two studied factors (tables 5 and 6) showed significan differences between weed control treatments for technical length, 1000 seed weight, number of basa branches per plant, seed yield per plant and fruiting zone length, and these differences varied according to the applied seeding rate. With regard to technical length, the highest value was obtained from the weedy check and the highest seeding rate, whereas the lowest value was recorded for Brominal and Granstar at the lowest seeding rate, in both seasons. The remaining characters showed a decreasing trend with increasing seeding rate, where the magnitude of reduction was highest at the highest seeding rate. The herbicides combination of Brominal + Select Super gave the highest values, whereas the weedy check gave the lowest values in the two seasons. The results obtained from the present investigation revealed that increasing seeding rates provide supplemental weed control, especially broad-leaved weeds. The implementation of seeding rate as an integrated weed management practice will be dependent on herbicide and flax seed costs, and the revenue loss from flax - weed interference. Moreover, the combinations between herbicides for broad and narrow-leaved weeds are recommended, over individual herbicides, for controlling both weed categories in the flax crop, since they were comparable, or even superior, to the conventional method of hand hoeing twice especially with the increasing labor costs.

Table 5: Means of Broad-leaved weeds dry weight, Technical length, 1000 seed weight, Number of basal

branches and Seed yield per Plant as affected by seeding rates and weed control treatments interactions in 2012/2013 season.

\begin{tabular}{|c|c|c|c|c|c|c|}
\hline $\begin{array}{l}\text { Seeding } \\
\text { rate }\end{array}$ & Weed control treatments & $\begin{array}{c}\text { Broad- } \\
\text { leaved weeds } \\
\text { dry weight } \\
\text { (g) } \\
\end{array}$ & $\begin{array}{c}\text { Technical } \\
\text { length } \\
(\mathrm{cm})\end{array}$ & $\begin{array}{c}1000 \text { seed } \\
\text { weight } \\
\text { (g) }\end{array}$ & $\begin{array}{c}\text { No. of } \\
\text { basal } \\
\text { branches }\end{array}$ & $\begin{array}{c}\text { Seed } \\
\text { yield/ } \\
\text { Plant } \\
(g)\end{array}$ \\
\hline \multirow{8}{*}{$\mathrm{D}_{1} 30 \mathrm{~kg}$} & Stomp & 25.67 & 71.5 & 9.2 & 2.33 & 1.43 \\
\hline & Brominal & 18.33 & 68.8 & 9.6 & 2.07 & 1.29 \\
\hline & Granstar & 20.33 & 69.0 & 8.8 & 1.43 & 1.08 \\
\hline & Select Super & 298.3 & 71.1 & 8.6 & 1.87 & 1.21 \\
\hline & Brominal + Select Super & 24.00 & 74.9 & 10.5 & 2.73 & 1.82 \\
\hline & Granstar + Select Super & 28.00 & 70.3 & 9.2 & 2.17 & 1.40 \\
\hline & Hand hoeing twice & 26.40 & 73.2 & 10.0 & 2.50 & 1.67 \\
\hline & Unweeded control & 303.1 & 77.2 & 7.9 & 1.37 & 1.00 \\
\hline \multirow{8}{*}{$\mathrm{D}_{2} 45 \mathrm{~kg}$} & Stomp & 21.00 & 75.3 & 8.5 & 2.03 & 1.21 \\
\hline & Brominal & 15.44 & 71.2 & 9.3 & 1.73 & 1.18 \\
\hline & Granstar & 17.00 & 74.4 & 8.3 & 1.40 & 1.05 \\
\hline & Select Super & 285.0 & 73.3 & 8.4 & 1.50 & 1.11 \\
\hline & Brominal + Select Super & 21.33 & 79.1 & 9.9 & 2.23 & 1.41 \\
\hline & Granstar + Select Super & 22.33 & 73.4 & 8.7 & 1.83 & 1.22 \\
\hline & Hand hoeing twice & 23.67 & 75.5 & 9.4 & 2.10 & 1.45 \\
\hline & Unweeded control & 286.3 & 81.2 & 7.5 & 1.20 & 1.00 \\
\hline \multirow{8}{*}{$\mathrm{D}_{3} 60 \mathrm{~kg}$} & Stomp & 19.00 & 79.1 & 7.7 & 1.63 & 1.09 \\
\hline & Brominal & 13.93 & 73.6 & 8.5 & 1.30 & 1.08 \\
\hline & Granstar & 15.00 & 74.4 & 8.3 & 1.00 & 0.98 \\
\hline & Select Super & 284.4 & 74.1 & 7.5 & 1.33 & 0.97 \\
\hline & Brominal + Select Super & 19.67 & 82.7 & 9.1 & 1.83 & 1.35 \\
\hline & Granstar + Select Super & 20.33 & 75.4 & 7.9 & 1.40 & 1.11 \\
\hline & Hand hoeing twice & 22.67 & 78.4 & 8.9 & 1.67 & 1.31 \\
\hline & Unweeded control & 273.7 & 84.4 & 6.8 & 1.00 & 0.82 \\
\hline L. S. D.0.05 & & 2.95 & 1.4 & 0.4 & 0.07 & 0.09 \\
\hline
\end{tabular}


Table 6: Means of Broad-leaved weeds dry weight, Technical length, 1000 seed weight, Number of basal branches and Seed yield per Plant and Fruiting zone length as affected by seeding rates and weed control treatments interactions in 2013/2014 season.

\begin{tabular}{|c|c|c|c|c|c|c|c|}
\hline $\begin{array}{l}\text { Seeding } \\
\text { rate }\end{array}$ & $\begin{array}{l}\text { Weed control } \\
\text { treatments }\end{array}$ & $\begin{array}{c}\text { Broad- } \\
\text { leaved } \\
\text { weeds dry } \\
\text { weight (g) }\end{array}$ & $\begin{array}{c}\text { Technical } \\
\text { length } \\
(\mathrm{cm})\end{array}$ & $\begin{array}{c}1000 \\
\text { seed } \\
\text { weight } \\
(\mathrm{g}) \\
\end{array}$ & $\begin{array}{c}\text { No. of } \\
\text { basal } \\
\text { branches }\end{array}$ & $\begin{array}{c}\text { Seed } \\
\text { yield/ } \\
\text { Plant } \\
(g) \\
\end{array}$ & $\begin{array}{c}\text { Fruiting } \\
\text { zone } \\
\text { length } \\
\text { (cm) } \\
\end{array}$ \\
\hline \multirow{8}{*}{$\mathrm{D}_{1} 30 \mathrm{~kg}$} & Stomp & 60.00 & 67.5 & 8.5 & 2.13 & 1.32 & 18.4 \\
\hline & Brominal & 7.66 & 65.0 & 8.8 & 1.90 & 1.19 & 16.0 \\
\hline & Granstar & 8.33 & 65.1 & 8.1 & 1.33 & 0.99 & 15.2 \\
\hline & Select Super & 333.3 & 67.1 & 8.0 & 1.73 & 1.07 & 15.6 \\
\hline & $\begin{array}{l}\text { Brominal + Select } \\
\text { Super }\end{array}$ & 28.33 & 70.7 & 9.7 & 2.53 & 1.68 & 19.9 \\
\hline & Granstar + Select Super & 16.33 & 66.4 & 8.6 & 2.00 & 1.29 & 18.1 \\
\hline & Hand hoeing twice & 23.34 & 69.0 & 9.3 & 2.30 & 1.57 & 19.7 \\
\hline & Unweeded control & 310.1 & 72.8 & 7.3 & 1.30 & 0.92 & 13.5 \\
\hline \multirow{8}{*}{$\mathrm{D}_{2} 45 \mathrm{~kg}$} & Stomp & 56.0 & 71.1 & 8.1 & 1.83 & 1.17 & 17.3 \\
\hline & Brominal & 5.00 & 68.2 & 8.7 & 1.53 & 1.10 & 15.5 \\
\hline & Granstar & 6.11 & 70.3 & 7.7 & 1.20 & 0.96 & 15.4 \\
\hline & Select Super & 321.7 & 69.1 & 7.8 & 1.30 & 1.01 & 14.8 \\
\hline & $\begin{array}{l}\text { Brominal + Select } \\
\text { Super }\end{array}$ & 23.33 & 74.7 & 9.3 & 2.03 & 1.38 & 18.8 \\
\hline & Granstar + Select Super & 12.63 & 69.3 & 8.2 & 1.63 & 1.13 & 17.3 \\
\hline & Hand hoeing twice & 14.01 & 71.3 & 8.9 & 1.90 & 1.35 & 18.5 \\
\hline & Unweeded control & 290.3 & 76.7 & 7.1 & 1.00 & 0.81 & 13.1 \\
\hline \multirow{8}{*}{$\mathrm{D}_{3} 60 \mathrm{~kg}$} & Stomp & 44.33 & 74.6 & 7.4 & 1.53 & 1.01 & 16.6 \\
\hline & Brominal & 3.33 & 69.5 & 8.1 & 1.30 & 0.98 & 14.6 \\
\hline & Granstar & 5.13 & 70.2 & 7.4 & 0.97 & 0.86 & 13.8 \\
\hline & Select Super & 319.3 & 69.7 & 7.2 & 1.23 & 0.89 & 14.3 \\
\hline & $\begin{array}{l}\text { Brominal + Select } \\
\text { Super }\end{array}$ & 21.00 & 78.1 & 8.8 & 1.83 & 1.27 & 18.1 \\
\hline & Granstar + Select Super & 10.64 & 71.2 & 7.6 & 1.40 & 1.03 & 16.7 \\
\hline & Hand hoeing twice & 16.67 & 74.2 & 8.5 & 1.67 & 1.21 & 18.1 \\
\hline & Unweeded control & 278.7 & 80.0 & 6.5 & 1.00 & 0.72 & 12.2 \\
\hline L. S. D. 0.05 & & 4.01 & 1.3 & 0.1 & 0.07 & 0.05 & 0.1 \\
\hline
\end{tabular}

\section{REFERENCES}

Abd-El-Daiem, M. A. M. 2004. Evaluation of some flax genotypes under different plant densities. M. Sc. Thesis, Fac. of Agric., Al-Azhar Univ.,Egypt.

Abd El-Samie, F. S. and M. A. Abd El-Dayem 2000. Effect of seeding patterns, tillage systems and weed control on yield and quality of flax. Fayoum J. Agric., Res. \& Dev., 14: 175-188.

Abou-zaid, T. A. and A. M. Al-Azoy. 2003. Response of flax to leveling, planting methods and seeding rates. J. Agric. Sci. Mansoura Univ., 28 (9): 6577-6589.

El-Deeb, I. A. E., N. A. Mohamed and Eman, A. E. El-Kady. 2006. Effect of seeding rates, planting methods and phosphorous fertilizer sources on yield and its components of Sakha 2 flax cultivar. Zagazig J. Agric. Res., 33 (1): 27-45
Ghalwash, A. M. and I. E. Soliman. 2007. Efficacy of some weed control treatments on annual weeds, growth characters and yield and its components of flax (Linum usitatissimum L). Egypt J. Agric. Res., 68 (1): 383-394.

Gomez, K. A. and A. A. Gomez. 1984. Statistical Procedures for Agriculture Research. $2^{\text {nd }}$ ed. John Wiley and Sons, New York, USA.

Kassem, M. M. 1992. Productivity of flax variety "Giza 6" as affected by some weed control treatments and seeding rates. Ann. Agric. Sci., Moshtohor, 50 (1): 145-156.

Kineber, M. E. A. 2003. Flax plants performance as influenced by planting methods and seeding rate. J. Agric. Tanta Univ., 29 (1): 64-73.

Kineber, M. E. A., A. A. E. Mahmoud and E. A. F. El-Kady. 1997. Influence of planting method and seeding rate on yield and its components of some flax genotypes. J. Agric. Tanta Univ., 23 (3): 264-274. 
Lafond, G. P. 1993. The effects of nitrogen, row spacing and seeding rate on the yield of flax under a zero-till production system. Can. J. Plant Sci., 73 (2): 375-382.

Mostafa, S. H. A. 2003. Response of Sakha 1 and Sakha 2 flax varieties to harvesting times and plant densities. $10^{\text {th }}$ National Con. of Agron. Fac. Environ. Agric. Sci. El-Arish Sues Canal Univ. October, 7-10.

Mousa, A. M. 2002. Effect of weed control on yield and quality for some genotypes in flax. M. Sc. Thesis, Fac. of Agric. Al-Azhar Univ., Egypt.

Osman, M. S., A. M. Okaz, E. E. Hassanein and E. M. El-Ninny. 2010. Effect of flax varieties, weed control methods under two different sowing methods on weeds and flax crop and its quality. Egypt. J. Agric. Res., 88 (4): 1293 1309.
Siddique, A. B., D. Wright, A. Khatun and Z. Naher. 2003. Studies on the effects of capsule position on the mother plant and sowing density on flowering, capsule production, seed yield, yield components and viability (germination) of flax seeds. Pakistan J. Biol. Sci., 6 (10): 939944

Stevenson F. C. and A. T. Wright. 1996. Seeding rate and row spacing affect flax yields and weed interference. Can. J. Plant Sci., 76 (3): 537-544. Swanton, C. J. and C. J. Wiese. 1991. Integrated weed management: the ration and approach. Weed Technol., 5 (3): 657-663.

Zedan, Z. A. Z. 2004. Response of some flax varieties to planting methods and planting densities. Egypt. J. Appl. Sci., 19 (9 A): 108121.

تأثير معدلات التقاوى ومعاملات مقاومة الحشائش على إنتاجية وتقليل الحشائش فى صنف

الكتان سخا ع

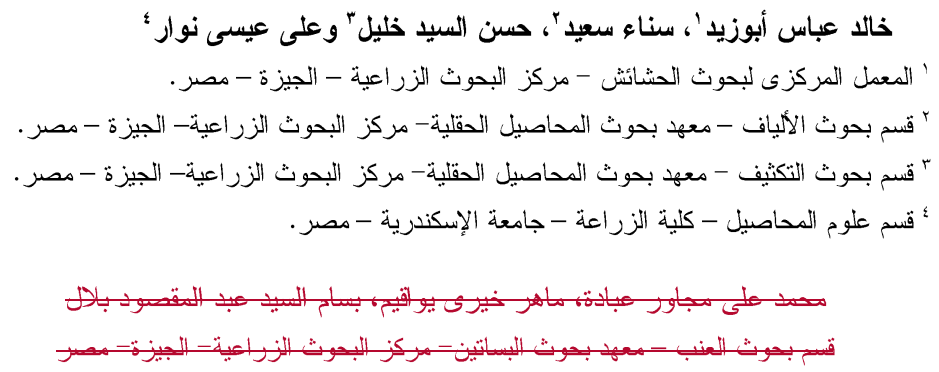




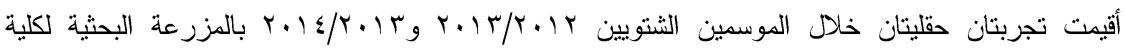
الزر اعة، جامعة الإسكندرية لار اسة تأثير ثلاثة معدلات زر اعة(•r و م؛ و • ج كجم/ف) وثمانى معاملات لمكافحة الحثائش على الصفات الخضرية و المحصولية للكتان- صنف سخا ؟ - و الحشائش المصاحبة له. وجد أنه بزيادة معدل الزر اعة لم يثأثز معنوياً الوزن الجاف لكل من الحشائش عريضة وضيقة الأوراق والوزن ولئن الجاف للحشائش الكلية، فى كلا الموسمين. كان تطبيق معاملة برومينال + سلكت سوبر أفضل من النقاوة البدوية مرتين كما أدى تطبيق مبيدات الحشائش منفردة، سواء قبل أو بعد الانبثاق، إلى تقليل كلا نوعى الحشائش و الحشائش الكلية.

بزيادة معدل الزراعة أزداد معنويا كل من ارتفاع النبات، الطول الفعال، محصول البذور والمحصول البيولوجى، بينما أنخفض معنوياً كل من عدد الكبسولات للنبات، وزن .. .. بذرة، طول المنطقة الثمرية، عدد الأفرع القاعدية و الثمرية ومحصول البذور للنبات. لتانئ. أدى تطبيق معاملة برومينال + سلكت سوبر بعد الانبثاق إلى زيادة معنوية فى محصول البذور ومكوناته بالمقارنة باستخدام مبيدات الحثائش منفردة، قبل أو بعد الانبثاق، أو النقارة اليدوية مرنين، في كلا الموسمين.

Formatted: Font: Not Bold, Complex Script Font: Times New Roman, Not Bold 